\title{
Audiências de Custódia como Política Pública para a Redução do Encarceramento no Rio de Janeiro
}

\author{
Thaís Lima \\ Universidade do Estado do Rio de Janeiro, Programa de Pós-Graduação em Direito Público, \\ Rio de Janeiro/RJ, Brasil. E-mail: thaisslima@icloud.com
}

"Cada país tem o número de presos que decide politicamente ter." ${ }^{1}$

\section{Resumo}

Em 2015, o Conselho Nacional de Justiça (CNJ) lançou o projeto "Audiência de Custódia", que almejava, como política pública, reduzir o número de presos provisórios no País. $O$ Brasil já tinha quase 700 mil pessoas encarceradas, dentre as quais $40 \%$ ainda não tinham sido condenadas. O presente artigo analisou os resultados dos primeiros anos de implementação das audiências de custódia no Estado do Rio de Janeiro, entre 2015 e 2019. A análise da experiência fluminense, apesar de não abranger a diversidade das dificuldades enfrentadas pelo Projeto do CNJ nas várias regiões do País, mostrou que as audiências de custódia têm o potencial efeito de desacelerar o incremento da população prisional. Por outro lado, a pesquisa revelou que o comportamento dos juízes, imersos numa cultura de encarceramento, se apresenta como um importante obstáculo que reduz a efetividade da política pública. Mas, quando aplicadas medidas como programas de capacitação, exigência de experiência prévia na área criminal e escolha dos magistrados a partir de editais de inscrição com critérios objetivos, os dados indicaram maiores índices de concessão de liberdade nas audiências de custódia. Ao final, conclui-se que tais medidas tornaram as audiências de custódia mais efetivas para fins de redução da curva do encarceramento no Estado do Rio de Janeiro

Palavras-chave

Audiência de Custódia; Presos Provisórios; Superencarceramento; Direitos Humanos; Estado de Coisas Inconstitucional

\footnotetext{
1 ZAFFARONI, Eugenio Raúl. 'Cada país tem o número de presos que decide politicamente ter'. [Entrevista cedida a] Viviane Tavares. EPSJV/Fiocruz, Rio de Janeiro, 15 jul. 2013, 8:45, atualizado em 05 abr. 2016, 11:47. Disponível em: http://www.epsjv.fiocruz.br/noticias/entrevista/cada-pais-tem-o-numero-de-presos-quedecide-politicamente-ter. Acesso em: 28 set. 2019.
} 


\section{Custody Hearings as a Public Policy for Reducing Incarceration in Rio de Janeiro}

\section{Abstract}

In 2015, the National Council of Justice (Conselho Nacional de Justiça - CNJ) launched the "Custody Hearing Project" (Projeto Audiência de Custódia), which aimed, as a public policy, to reduce the number of pretrial detainees in the country. Brazil already had almost 700,000 people incarcerated, among which $40 \%$ had not yet been tried. This article analyzed the results of the first years of implementation of custody hearings in the State of Rio de Janeiro, between 2015 and 2019. The analysis of this experience, although it does not cover the diversity of difficulties faced by the CNJ Project in the various regions of the country, shown that custody hearings have the potential effect of slowing the increase of the prison population. On the other hand, a survey revealed that the behavior of judges, immersed in a culture of incarceration, presents itself as an important obstacle that reduces the effectiveness of this public policy. However, when measures are applied such as training programs, the requirement of previous experience in the criminal area and the choice of judges based on objective criteria, the data indicated higher rates of freedom granted in custody hearings. In the end, the conclusion is that such measures made custody hearings more effective for the purpose of reducing the incarceration curve in the State of Rio de Janeiro.

Keywords

Custody Hearing; Pretrial Detainees; Mass Incarceration; Human Rights; Unconstitutional State of Affairs.

\section{Sumário}

Introdução; 1. O Estado de Coisas Inconstitucional do Sistema Penitenciário e a Imprescindibilidade da Redução do Encarceramento Cautelar no Brasil; 2. Uma Política Pública para o Desencarceramento: Audiências de Custódia; 3. Monitoramento dos Resultados das Audiências de Custódia para Fins de Redução do Encarceramento Cautelar: Relatórios e Dados de Pesquisa; 4. Análise dos Resultados: um Estudo de Caso do Estado do Rio De Janeiro; 5. A Cultura do Encarceramento: Um Obstáculo aos Objetivos de Redução dos Presos Provisórios por Meio das Audiências de Custódia; Conclusão; Referências. 


\section{Introdução}

O Pacto Internacional sobre Direitos Civis e Políticos² e a Convenção Americana sobre Direitos Humanos (Pacto de São José da Costa Rica) 3 preveem que toda pessoa detida tem o direito de ser conduzida, sem demora, à presença de uma autoridade judicial. Mas, em que pese o Brasil seja signatário dos referidos documentos internacionais desde $1992^{4}$, tal garantia somente começou a se tornar realidade a partir do Projeto Audiência de Custódia, lançado pelo Conselho Nacional de Justiça (CNJ) em 2015. Trata-se de uma política pública que, dentre outros objetivos, pretende reduzir o número de presos provisórios nos estabelecimentos prisionais.

O presente trabalho analisa os resultados obtidos por essa política pública na redução do encarceramento cautelar e mitigação do problema da superlotação dos presídios no Estado do Rio de Janeiro. Para tanto foram analisados dados obtidos no âmbito desta unidade federativa, de setembro de 2015 a agosto de 2019, período no qual as audiências de custódia foram implementadas e expandidas, até abranger todo o Estado.

Diante das inúmeras disparidades regionais na implementação das audiências de custódia pelo País (ex.: estrutura física e humana do Poder Judiciário, dificuldade das instituições policiais no transporte dos presos, existência ou não de defensores públicos em número suficiente para atender à demanda de defesa etc. ${ }^{5}$ ), é evidente que não há como extrair conclusões aplicáveis em âmbito nacional a partir deste estudo limitado ao Estado do Rio de Janeiro. Mas, por outro lado, a análise da experiência fluminense na realização das audiências de custódia poderá fornecer alguns subsídios para o enfrentamento de, ao menos, alguns obstáculos comuns aos demais entes federativos, além de, evidentemente, permitir melhorias no âmbito do próprio Rio de Janeiro.

\footnotetext{
2 Artigo 9o, item 3: "Qualquer pessoa presa ou encarcerada em virtude de infração penal deverá ser conduzida, sem demora, à presença do juiz ou de outra autoridade habilitada por lei a exercer funções judiciais e terá o direito de ser julgada em prazo razoável ou de ser posta em liberdade. A prisão preventiva de pessoas que aguardam julgamento não deverá constituir a regra geral, mas a soltura poderá estar condicionada a garantias que assegurem o comparecimento da pessoa em questão à audiência, a todos os atos do processo e, se necessário for, para a execução da sentença".

${ }^{3}$ Artigo 80, item 5: "Toda pessoa detida ou retida deve ser conduzida, sem demora, à presença de um juiz ou outra autoridade autorizada pela lei a exercer funções judiciais e tem direito a ser julgada dentro de um prazo razoável ou a ser posta em liberdade, sem prejuízo de que prossiga o processo. Sua liberdade pode ser condicionada a garantias que assegurem o seu comparecimento em juízo".

${ }^{4}$ BRASIL. Decreto 592, de 6 de julho de 1992. Atos Internacionais. Pacto Internacional sobre Direitos Civis e Políticos. Promulgação. Diário Oficial da União: seção 1, Brasília, DF, p. 8716, 7 jul. 1992. BRASIL. Decreto 678, de 6 de novembro de 1992. Promulga a Convenção Americana sobre Direitos Humanos (Pacto de São José da Costa Rica), de 22 de novembro de 1969. Diário Oficial da União: seção 1, Brasília, DF, p. 15562, 9 nov. 1992. ${ }^{5}$ Para uma análise sobre algumas variáveis regionais, v. INSTITUTO DE DEFESA DO DIREITO DE DEFESA. 0 fim da liberdade: a urgência de recuperar o sentido e a efetividade das audiências de custódia. São Paulo: IDDD, 2019, p. 32. Disponível em: http://www.iddd.org.br/wpcontent/uploads/2020/07/OFimDaLiberdade_completo.pdf. Acesso em 28 set. 2019.
} 


\section{O Estado de Coisas Inconstitucional do Sistema Penitenciário}

\section{e a Imprescindibilidade da Redução do Encarceramento Cautelar}

\section{no Brasil}

O Brasil tinha 90 mil presos em 1990, e em 2017 passou a ter 726.3546, ou seja, um aumento de 707\%. Entre 1991 e 2010 o aumento foi de quase 452\%, enquanto o crescimento da população em geral, no período de 1991 a 2010, foi de cerca de $30 \%{ }^{7}$.



Por outro lado, em junho de 2017, havia apenas 423.242 vagas no sistema carcerário do País, o que acarretava uma taxa de ocupação de 171,62\%. Além disso, 235.241 eram presos sem condenação, o equivalente a uma parcela de $32,39 \%^{8}$.

A superlotação nos presídios brasileiros não é novidade. Em 2009, o relatório da Comissão Parlamentar do Inquérito (CPI) do Sistema Carcerário, realizada pela Câmara dos Deputados, já revelava que "a superlotação é um grave problema e aflige a grande maioria dos estabelecimentos prisionais", e que são "extremamente raras as unidades que respeitam a capacidade inaugural ou projetada ${ }^{\prime \prime 9}$. Cumpre destacar que este relatório fazia menção a outro, de 1976, também produzido

\footnotetext{
${ }^{6}$ BRASIL. Departamento Penitenciário Nacional. Levantamento nacional de informações penitenciárias: atualização junho de 2017. Brasília: DEPEN, 2019.

${ }^{7}$ A população brasileira total era de IBGE era de 146.825.475, em 1991, e 190.755.799 em 2010. BRASIL. Instituto Brasileiro de Geografia e Estatística. Brasil em síntese. Brasília: IBGE, 2019. Disponível em: https://brasilemsintese.ibge.gov.br/populacao/populacao-total-1980-2010.html. Acesso em 28 set. 2019.

8 BRASIL. Departamento Penitenciário Nacional. Levantamento nacional de informações penitenciárias: atualização junho de 2017. Brasília: DEPEN, 2019.

9 CÂMARA DOS DEPUTADOS (Brasil). Relatório final da Comissão Parlamentar de Inquérito do Sistema Carcerário. Brasília: Câmara dos Deputados, 2009, p. 241/247.
} 
por uma CPI parlamentar, no qual se apontava o mesmo problema ${ }^{10}$.

Em 25/9/2019, a imprensa noticiou que, em Porto Alegre, cem presos vivem algemados a 18 viaturas da polícia, numa cadeia a céu aberto. E “quem chega por último na 'cela' é algemado na porta aberta do carona do veículo. Quem está ali há mais tempo, 'progride' para o fundo do camburão"11.

Se as causas do crescimento da população prisional são complexas, suas consequências são muito claras. $\mathrm{O}$ uso excessivo da prisão leva a condições desumanas e degradantes, impõe enormes custos ao Estado e limita a capacidade dos sistemas prisionais de lidar efetivamente com a pequena minoria de prisioneiros que representa sérios riscos à segurança pública ${ }^{12}$.

Não é à toa, portanto, que foi reconhecido pelo Supremo Tribunal Federal, na ADPF $347^{13}$, o estado de coisas inconstitucional do sistema carcerário brasileiro. A superlotação dos presídios provoca a massiva violação de direitos fundamentais das pessoas privadas de liberdade e, nas palavras do Ministro Relator da referida ação, "pode ser a origem de todos os males".

Portanto, nenhuma solução para as graves violações de direitos humanos no sistema prisional brasileiro funcionará se não houver uma séria política pública de desencarceramento.

10 CÂMARA DOS DEPUTAdOS (Brasil). Relatório final da Comissão Parlamentar de Inquérito do Sistema Carcerário. Brasília: Câmara dos Deputados, 2009, p. 246.

11 JACOBSEN, Gabriel. Algemados a 18 viaturas, quase cem presos vivem em "cadeia a céu aberto" em Porto Alegre. Jornal GaúchaZH, Porto Alegre, 25 set. 2019. Disponível em: https://gauchazh.clicrbs.com.br/seguranca/noticia/2019/09/algemados-a-18-viaturas-quase-cem-presosvivem-em-cadeia-a-ceu-aberto-em-porto-alegre-ck0zjtvte00p701 mtpx6x76o1.html. Acesso em: 28 set. 2019. 12 JACOBSON, Jessica, HEARD, Catherine e FAIR, Helen. Prison: Evidence of its use and over-use from around the world. Londres: Institute for Criminal Policy Research, 2017, p. 7.: "The causes of prison population growth are complex, but many of the consequences are clear. Over-use of imprisonment leads to overcrowded, inhumane and degrading conditions of detention. It disproportionately harms poor and marginalised groups in all societies. It limits the capacity of prison systems to deal effectively with the small minority of prisoners who pose serious risks to public safety, and indeed increases the risks posed by prisoners (to themselves as well as to others inside and outside prison walls). Over-use of imprisonment also imposes enormous costs on the public purse".

${ }^{13}$ BRASIL. Supremo Tribunal Federal (Tribunal Pleno). Arguição de Descumprimento de Preceito Fundamental 347 (Medida Cautelar). CUSTODIADO - INTEGRIDADE FÍSICA E MORAL - SISTEMA PENITENCIÁRIO ARGUIÇÃO DE DESCUMPRIMENTO DE PRECEITO FUNDAMENTAL - ADEQUAÇÃO. Cabível é a arguição de descumprimento de preceito fundamental considerada a situação degradante das penitenciárias no Brasil. SISTEMA PENITENCIÁRIO NACIONAL - SUPERLOTAÇÃO CARCERÁRIA - CONDIÇÕES DESUMANAS DE CUSTÓDIA - VIOLAÇÃO MASSIVA DE DIREITOS FUNDAMENTAIS - FALHAS ESTRUTURAIS - ESTADO DE COISAS INCONSTITUCIONAL - CONFIGURAÇÃO. Presente quadro de violação massiva e persistente de direitos fundamentais, decorrente de falhas estruturais e falência de políticas públicas e cuja modificação depende de medidas abrangentes de natureza normativa, administrativa e orçamentária, deve o sistema penitenciário nacional ser caraterizado como "estado de coisas inconstitucional". FUNDO PENITENCIÁRIO NACIONAL VERBAS - CONTINGENCIAMENTO. Ante a situação precária das penitenciárias, o interesse público direciona à liberação das verbas do Fundo Penitenciário Nacional. AUDIÊNCIA DE CUSTÓDIA - OBSERVÂNCIA OBRIGATÓRIA. Estão obrigados juízes e tribunais, observados os artigos 9.3 do Pacto dos Direitos Civis e Políticos e 7.5 da Convenção Interamericana de Direitos Humanos, a realizarem, em até noventa dias, audiências de custódia, viabilizando o comparecimento do preso perante a autoridade judiciária no prazo máximo de 24 horas, contado do momento da prisão. Relator: Min. Marco Aurélio, 9 set. 2015. Diário da Justiça Eletrônico: 19 fev. 2016.

Revista Publicum

Rio de Janeiro, v. 6, n. 1, p. 42-69, 2020

http://www.e-publicacoes.uerj.br/index.php/publicum

DOI: $10.12957 /$ publicum.2020.56183 
O aumento exponencial do encarceramento é um fenômeno mundial. Desde 2000 a população carcerária do planeta cresceu $24 \%$. Estima-se que no mundo haja 11 milhões de pessoas encarceradas e o Brasil ocupa a terceira posição no ranking dos países com os maiores números absolutos de presos, perdendo apenas para os Estados Unidos, que concentra 1/3 da população prisional do mundo, e para a China ${ }^{14}$.

Por outro lado, entre 2015 e 2018, tanto os Estados Unidos quanto a China tiveram redução no número de presos, respectivamente em $4 \%$ e 0,5\%. Já o Brasil, no mesmo período, aumentou sua população prisional em $14 \%{ }^{15}$. Eugenio Raúl Zaffaroni afirmou em 2013 que "cada país tem o número de presos que decide politicamente ter"16.

Com efeito, nos últimos 15 anos, alguns países têm empreendido esforços para reduzir o número de presos ou, ao menos, frear seu crescimento: Itália ${ }^{17}$, Rússia, Chile e Portugal, além do Estado da Califórnia, nos Estados Unidos ${ }^{18}$. O Brasil também precisa de forma urgente implementar uma política pública efetiva de desencarceramento, pois os esforços empreendidos até o momento não lograram êxito em reduzir a população carcerária do País.

A Lei 12.403/2011 pretendeu reduzir o número de presos provisórios no Brasil. No início da vigência da lei, havia no País 173.810 presos provisórios, o que corresponde a 33,8\% do total de pessoas privadas da liberdade. Passados quatro anos, em 2015, o Brasil tinha 261.780 presos provisórios, ou 40,1\% do total de encarcerados ${ }^{19}$.

\footnotetext{
${ }^{14}$ WALMSLEY, Roy. World Prison Population List. 12th ed. Londres: Institute For Criminal Policy Research, 06 nov. $2018 . \quad$ Disponível em: https://www.prisonstudies.org/sites/default/files/resources/downloads/wppl_12.pdf. Acesso em 28 set. 2019.

15 WALMSLEY, Roy. World Prison Population List. 12th ed. Londres: Institute For Criminal Policy Research, 06 nov. $2018 . \quad$ Disponível em: https://www.prisonstudies.org/sites/default/files/resources/downloads/wppl_12.pdf. Acesso em 28 set. 2019.

16 ZAFFARONI, Eugenio Raúl. 'Cada país tem o número de presos que decide politicamente ter'. [Entrevista cedida a] Viviane Tavares. EPSJV/Fiocruz, Rio de Janeiro, 15 jul. 2013, 8:45, atualizado em 05 abr. 2016, 11:47. Disponível em: http://www.epsjv.fiocruz.br/noticias/entrevista/cada-pais-tem-o-numero-de-presos-quedecide-politicamente-ter. Acesso em: 28 set. 2019.

17 Para uma breve, mas esclarecedora análise da Itália a partir do caso Torreggiani e altri contra Itália, v. PALMA, Mauro. O caso italiano a partir de uma sentença piloto. Epílogo da obra de BEIRAS, Iñaki Rivera. Desencarceramento: por uma política de redução da prisão a partir de um garantismo radical. Florianópolis: Tirant Lo Blanch, 2019, p. 171-190.

18 Para uma análise dos casos de Rússia, Chile e Portugal e do Estado da Califórnia, nos Estados Unidos, v. PASTORAL CARCERÁRIA. Luta antiprisional no mundo contemporâneo: um estudo sobre experiências de redução da população carcerária em outras nações. São Paulo: Pastoral Carcerária, 2018. Disponível em: https://carceraria.org.br/wp-content/uploads/2018/09/relatorio_luta_antiprisional.pdf. Acesso em 28 set. 2019.

19 BRASIL. Departamento Penitenciário Nacional. Levantamento nacional de informações penitenciárias:
} atualização junho de 2017. Brasília: DEPEN, 2019. 


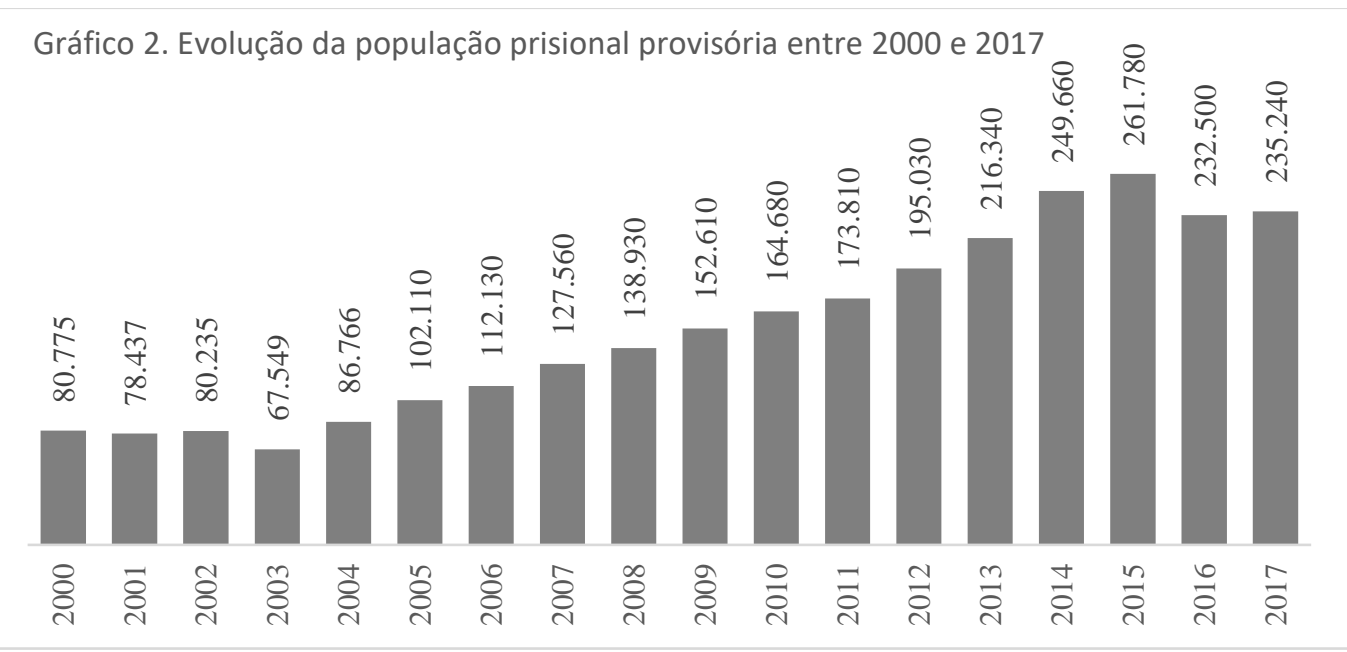

A partir de 2015, com a implementação, ainda que progressiva, das audiências de custódia, o número de presos provisórios foi reduzido para 232.500 em 2016. Em 2017, por sua vez, ocorreu certa estabilização em $235 \cdot 240^{20}$. Contudo, o número total de presos no Brasil, como visto no gráfico 1, continua a crescer, o que significa que nenhuma das medidas operaram de forma efetiva para o desencarceramento.

Em 2016, o Ministério da Justiça publicou a Portaria $n^{\circ} 495$ para instituir a Política Nacional de Alternativas Penais, com o objetivo de enfrentar o encarceramento em massa e reduzir em $10 \%$ o número de pessoas presas até o ano de 2019. Contudo, a meta não foi atingida e o que se viu foi o incremento da população prisional neste período.

Já em 2018, o Executivo Federal firmou compromisso com o CNJ para o repasse de 20 milhões de reais "para o desenvolvimento de estratégias para promover a redução da superlotação e superpopulação carcerária no Brasil, com enfoque nas políticas de alternativas penais e monitoração eletrônica de pessoas" ${ }^{21}$. E mais recentemente, o CNJ publicou a Resolução $\mathrm{n}^{\circ} 288$, de 25/6/2019, que define a "política institucional do Poder Judiciário para a promoção da aplicação de alternativas penais, com enfoque restaurativo, em substituição à privação de liberdade”.

${ }^{20}$ BRASIL. Departamento Penitenciário Nacional. Levantamento nacional de informações penitenciárias: atualização junho de 2017. Brasília: DEPEN, 2019.

21 BRASIL. Departamento Penitenciário Nacional; CONSELHO NACIONAL DE JUSTIÇA. Termo de Execução Descentralizada n. 010/2018. Dispõe sobre o desenvolvimento de estratégias para promover a redução da superlotação e superpopulação carcerária no Brasil, com enfoque nas políticas de alternativas penais e monitoração eletrônica de pessoas. Diário Oficial da União: seção 3, Brasília, DF, p. 125, 24 out. 2018.

Revista Publicum

Rio de Janeiro, v. 6, n. 1, p. 42-69, 2020

http://www.e-publicacoes.uerj.br/index.php/publicum

DOI: 10.12957/publicum.2020.56183 


\section{Uma Política Pública para o Desencarceramento: Audiências de}

\section{Custódia}

Em 22/1/2015, o Tribunal de Justiça do Estado de São Paulo (TJSP), unidade da federação que concentrava $1 / 3$ da população prisional do País ${ }^{22}$, publicou o Provimento Conjunto $n^{\circ}$ 03/2015 para a implantação gradativa das audiências de custódia, com o objetivo de reduzir o número de presos provisórios ${ }^{23}$.

A implementação das audiências de custódia encontrou seu primeiro obstáculo já no seu ponto de partida. Em 12/2/2015, a Associação dos Delegados de Polícia do Brasil - ADEPOL ajuizou a ação direta de inconstitucionalidade (ADI) $n^{\circ} 5240$ contra o provimento do TJSP. A entidade de classe já tinha se manifestado no Senado Federal durante o trâmite do Projeto de Lei n 554/2011, que pretende inserir, no corpo do Código de Processo Penal (CPP), a obrigatoriedade de apresentação da pessoa presa perante um juiz no prazo de 24 horas. Nas razões apontadas pela ADEPOL, já se anunciava um dos obstáculos que a implementação das audiências de custódia iria enfrentar: a cultura punitivista e encarceradora, de forte apelo popular ${ }^{24}$.

Contudo, o Supremo Tribunal Federal (STF) julgou improcedente o pedido na ADI $\mathrm{n}^{\circ} 5240$. O Ministro Relator, Luiz Fux, lembrou que "a prisão cautelar, que deveria ser a exceção num Estado Democrático de Direito que efetivamente preza pelo princípio da presunção de inocência, vem se tornando regra". E, por outro lado, destacou que as iniciativas dos Tribunais pioneiros, como o TJSP, demonstraram "a eficácia das audiências de custódia na redução da população de presos provisórios" 25 .

22 BRASIL. Departamento Penitenciário Nacional. Levantamento nacional de informações penitenciárias. Brasília: DEPEN, 2015.

23 TRIBUNAL DE JUSTIÇA DE SÃO PAULO. Corregedoria Geral da Justiça. Parecer. Processo no 2014/00153634. Corregedor Geral de Justiça: Des. Hamilton Elliot Akel, 30 out. 2014.

${ }^{24}$ Ao manifestar-se contrariamente ao projeto, a ADEPOL utiliza-se de um discurso ad terrorem: "Por fim, destacamos que, caso aprovada a proposição em comento, o Brasil enfrentaria uma verdadeira onda de impunidade, com o consequente aumento da criminalidade violenta. Isso porque as grandes dimensões de nosso território e a estrutura de nossas instituições, além de outros fatores, seriam importante obstáculo à efetivação sistemática da medida, o que geraria a nulidade de boa parte das prisões realizadas". ASSOCIAÇÃO DOS DELEGADOS DE POLÍCIA DO BRASIL. Nota técnica ao Projeto de Lei do Senado $n^{\circ} 554$, de 2011. Brasília: ADEPOL, 5 ago. 2014.

25 BRASIL. Supremo Tribunal Federal (Tribunal Pleno). Ação Direta de Inconstitucionalidade 5240/DF. AÇÃO DIRETA DE INCONSTITUCIONALIDADE. PROVIMENTO CONJUNTO 03/2015 DO TRIBUNAL DE JUSTIÇA DE SÃO PAULO. AUDIÊNCIA DE CUSTÓDIA. 1. A Convenção Americana sobre Direitos do Homem, que dispõe, em seu artigo 70, item 5, que "toda pessoa presa, detida ou retida deve ser conduzida, sem demora, à presença de um juiz", posto ostentar o status jurídico supralegal que os tratados internacionais sobre direitos humanos têm no ordenamento jurídico brasileiro, legitima a denominada "audiência de custódia", cuja denominação sugere-se "audiência de apresentação". 2. O direito convencional de apresentação do preso ao Juiz, consectariamente, deflagra o procedimento legal de habeas corpus, no qual o Juiz apreciará a legalidade da prisão, à vista do preso que lhe é apresentado, procedimento esse instituído pelo Código de Processo Penal, nos seus artigos 647 e seguintes. 3. O habeas corpus ad subjiciendum, em sua origem remota, consistia na determinação do juiz de apresentação do preso para aferição da legalidade da sua prisão, o que ainda se faz 
No mesmo ano, o Conselho Nacional de Justiça lançou o "Projeto Audiência de Custódia", por meio do Termo de Cooperação Técnica $n^{\circ} 7 / 2015$, firmado entre a referida instituição, 0 Ministério da Justiça e Instituto de Defesa do Direito de Defesa - IDDD. O objetivo era "oferecer opções concretas e factíveis ao encarceramento provisório de pessoas".

O tema voltou a ser abordado no Plenário do STF, em 9/9/2015, durante o julgamento da medida cautelar na ADPF $n^{\circ} 347$. A corte considerou que:

presente quadro de violação massiva e persistente de direitos fundamentais, decorrente de falhas estruturais e falência de políticas públicas e cuja modificação depende de medidas abrangentes de natureza normativa, administrativa e orçamentária, deve o sistema penitenciário nacional ser caraterizado como 'estado de coisas inconstitucional" 26.

E, como medida de redução da superpopulação carcerária, o STF determinou que juízes e tribunais estão obrigados, "observados os artigos 9.3 do Pacto dos Direitos Civis e Políticos e 7.5 da Convenção Interamericana de Direitos Humanos, a realizarem, em até noventa dias, audiências de custódia, viabilizando o comparecimento do preso perante a autoridade judiciária no prazo máximo de 24 horas, contado do momento da prisão" 27.

Na sequência, o CNJ editou a Resolução 213, de 15/12/2015, que determina que toda pessoa presa em flagrante delito, independentemente da motivação ou natureza do ato, seja

presente na legislação processual penal (artigo 656 do CPP). 4 . 0 ato normativo sob o crivo da fiscalização abstrata de constitucionalidade contempla, em seus artigos 1으, 3으, 5으, 6으 e 70 normas estritamente regulamentadoras do procedimento legal de habeas corpus instaurado perante o Juiz de primeira instância, em nada exorbitando ou contrariando a lei processual vigente, restando, assim, inexistência de conflito com a lei, o que torna inadmissível o ajuizamento de ação direta de inconstitucionalidade para a sua impugnação, porquanto o status do CPP não gera violação constitucional, posto legislação infraconstitucional. 5. As disposições administrativas do ato impugnado (artigos $2^{\circ}$, $4^{\circ} 8^{\circ}, 9^{\circ}, 10$ e 11), sobre a organização do funcionamento das unidades jurisdicionais do Tribunal de Justiça, situam-se dentro dos limites da sua autogestão (artigo 96, inciso I, alínea $a$, da CRFB). Fundada diretamente na Constituição Federal, admitindo ad argumentandum impugnação pela via da ação direta de inconstitucionalidade, mercê de materialmente inviável a demanda. 6. In casu, a parte do ato impugnado que versa sobre as rotinas cartorárias e providências administrativas ligadas à audiência de custódia em nada ofende a reserva de lei ou norma constitucional. 7. Os artigos 50, inciso II, e 22, inciso I, da Constituição Federal não foram violados, na medida em que há legislação federal em sentido estrito legitimando a audiência de apresentação. 8. A Convenção Americana sobre Direitos do Homem e o Código de Processo Penal, posto ostentarem eficácia geral e erga omnes, atingem a esfera de atuação dos Delegados de Polícia, conjurando a alegação de violação da cláusula pétrea de separação de poderes. 9. A Associação Nacional dos Delegados de Polícia - ADEPOL, entidade de classe de âmbito nacional, que congrega a totalidade da categoria dos Delegados de Polícia (civis e federais), tem legitimidade para propor ação direta de inconstitucionalidade (artigo 103, inciso IX, da CRFB). Precedentes. 10. A pertinência temática entre os objetivos da associação autora e o objeto da ação direta de inconstitucionalidade é inequívoca, uma vez que a realização das audiências de custódia repercute na atividade dos Delegados de Polícia, encarregados da apresentação do preso em Juízo. 11. Ação direta de inconstitucionalidade PARCIALMENTE CONHECIDA e, nessa parte, JULGADA IMPROCEDENTE, indicando a adoção da referida prática da audiência de apresentação por todos os tribunais do país. Relator: Min. Luiz Fux, 20 ago. 2015. Diário da Justiça Eletrônico: 1ํ fev. 2016.

${ }^{26}$ BRASIL. Supremo Tribunal Federal (Tribunal Pleno). Arguição de Descumprimento de Preceito Fundamental 347 (Medida Cautelar). Relator: Min. Marco Aurélio, 9 set. 2015. Diário da Justiça Eletrônico: 19 fev. 2016. 27 BRASIL. Supremo Tribunal Federal (Tribunal Pleno). Arguição de Descumprimento de Preceito Fundamental 347 (Medida Cautelar). Relator: Min. Marco Aurélio, 9 set. 2015. Diário da Justiça Eletrônico: 19 fev. 2016.

Revista Publicum

Rio de Janeiro, v. 6, n. 1, p. 42-69, 2020

http://www.e-publicacoes.uerj.br/index.php/publicum

DOI: 10.12957/publicum.2020.56183 
obrigatoriamente apresentada, em até 24 horas da comunicação do flagrante, à autoridade judicial competente, e ouvida sobre as circunstâncias em que se realizou sua prisão ou apreensão (artigo $\left.1^{\circ}\right)$

Ainda que, no seu nascedouro, a audiência de custódia tenha sido vista como um instrumento de desencarceramento cautelar, ela passou a ter, como sintetiza Caio Paiva, três finalidades: adequar o processo penal brasileiro aos tratados internacionais de direitos humanos, prevenir a prática da tortura policial e reduzir as prisões ilegais ou desnecessárias ${ }^{28}$.

Portanto, a realização da audiência de custódia, por ser uma imposição decorrente de tratados internacionais de direitos humanos, possui força cogente e independe de qualquer resultado que possa ou não produzir redução do encarceramento provisório no País. Assim, evidentemente, o Projeto de Decreto Legislativo $n^{\circ} 317 / 16$, de autoria do Deputado Federal Eduardo Bolsonaro, que pretende suspender a Resolução 213/2015 do CNJ sobre as audiências de custódia, padece de vício de convencionalidade ${ }^{29}$.

Por outro lado, a audiência de custódia é também uma política pública que visa à redução do superencarceramento no País, de forma a reduzir danos aos direitos fundamentais, o que justifica a análise dos resultados que produz nesse campo ${ }^{30}$.

\footnotetext{
${ }^{28}$ PAIVA, Caio. Audiência de custódia e o processo penal brasileiro. 3. ed. Boa Esperança-MG: Editora CEI, 2018, E-book.

${ }^{29} \mathrm{O}$ tema foi objeto do voto do Ministro Luiz Fux, relator da ADI 5.240, que discutia a constitucionalidade da implementação das audiências de custódia: "Esse caráter supralegal do tratado devidamente ratificado e internalizado na ordem jurídica brasileira - porém não submetido ao processo legislativo estipulado pelo art. 5o, § 3ㅇ, da CF/1988 - foi reafirmado pela edição da Súmula Vinculante 25, segundo a qual "é ilícita a prisão civil de depositário infiel, qualquer que seja a modalidade do depósito". Tal verbete sumular consolidou o entendimento deste Tribunal de que o art. 7ำ, item 7, da CADH teria ingressado no sistema jurídico nacional com status supralegal, inferior à CF/1988, mas superior à legislação interna, a qual não mais produziria qualquer efeito naquilo que conflitasse com a sua disposição de vedar a prisão civil do depositário infiel. Tratados e convenções internacionais com conteúdo de direitos humanos, uma vez ratificados e internalizados, ao mesmo passo em que criam diretamente direitos para os indivíduos, operam a supressão de efeitos de outros atos estatais infraconstitucionais que se contrapõem à sua plena efetivação". BRASIL. Supremo Tribunal Federal (Tribunal Pleno). Ação Direta de Inconstitucionalidade 5240/DF. Relator: Min. Luiz Fux, 20 ago. 2015. Diário da Justiça Eletrônico: 1o fev. 2016.

30 BARCELLOS, Ana Paula de. Políticas públicas e o dever de monitoramento: "levando os direitos a sério". Revista Brasileira de Políticas Públicas, Brasília, v. 8, n. 2, p. 251-265, 2018: "o monitoramento de políticas públicas em matéria de direitos fundamentais, e dos seus resultados em particular, é essencial para a promoção real desses direitos". E ainda: "Nesse contexto, o monitoramento envolve verificar se as metas que haviam sido estabelecidas quando da concepção da política estão sendo atingidas (caso, claro, elas tenham sido estabelecidas), acompanhar o que de fato está sendo executado no contexto da política em exame, e apurar os resultados concretos produzidos em face dos direitos fundamentais que se pretende promover, tendo em conta o problema que se pretendia solucionar por meio da política pública afinal. De tal modo que, diante desse conjunto de dados, seja possível rever a política ou aspectos dela de modo a aprimorar sua capacidade de promover os resultados desejados".
}

Revista Publicum

Rio de Janeiro, v. 6, n. 1, p. 42-69, 2020

http://www.e-publicacoes.uerj.br/index.php/publicum

DOI: 10.12957/publicum.2020.56183 


\section{Monitoramento dos Resultados das Audiências de Custódia para}

\section{Fins de Redução do Encarceramento Cautelar: Relatórios e Dados de}

\section{Pesquisa}

Desde 2015, já passados mais de 4 (quatro) anos do início das audiências de custódia, muitos dados já foram produzidos sobre seus resultados e, por isso, há muito material disponível.

Como o presente trabalho limita-se a uma análise no Estado do Rio de Janeiro, aqui foram analisados, principalmente ${ }^{31}$, os dados fornecidos pela Defensoria Pública desta unidade federativa, que monitora os resultados das audiências de custódia desde o início de sua implementação no Estado, em setembro de 2015. A instituição garante a presença de defensores públicos em todas as audiências de custódia quando a pessoa detida não está acompanhada de advogado. No primeiro ano, $93,61 \%^{32}$ das pessoas apresentadas foram assistidas pela Defensoria Pública, e, no segundo ano, o percentual foi de $96 \%{ }^{33}$. Assim, diante da expressiva participação da instituição, neste trabalho foram apenas analisados os casos de assistência por defensor público, o que é suficientemente representativo do total de audiências de custódia realizadas.

O quantitativo de pessoas encarceradas e presos cautelares foi obtido a partir dos dados da Secretaria de Administração Penitenciária do Estado do Rio de Janeiro (SEAP), que surpreendentemente divergem dos dados divulgados pelo Conselho Nacional de Justiça, muitas vezes reproduzidos em outros trabalhos. A título de exemplo, conforme os números do CNJ, em 6/8/2018, havia 77.950 presos do Estado do Rio de Janeiro ${ }^{34}$. Já pelos dados da SEAP, havia 51.881 presos no sistema carcerário estadual, na mesma data ${ }^{35}$. A disparidade de dados é enorme e foi necessário optar por uma fonte de dados.

A escolha pelos dados da SEAP deu-se em razão dos seguintes motivos: 1) o Grupo de Monitoramento e Fiscalização do Sistema Carcerário do Tribunal de Justiça do Estado do Rio de

31 Outros relatórios foram utilizados, sobretudo para avaliação do contexto nacional, e as fontes são indicadas em notas e nas referências bibliográficas.

32 DEFENSORIA PÚBLICA DO ESTADO DO RIO DE JANEIRO. Relatório: um ano de audiência de custódia no Rio de Janeiro. Rio de Janeiro: DPERJ, $2016 . \quad$ Disponível em: http://www.defensoria.rj.def.br/uploads/arquivos/53f2bf4ac82541 d3a0aa8bc6c6243c3e.pdf. Acesso em 28 set. 2019.

33 DEFENSORIA PÚBLICA DO ESTADO DO RIO DE JANEIRO. Relatório 2 ano das audiências de custódia no Rio de Janeiro. Rio de Janeiro: DPERJ, 2018. Disponível em http://www.defensoria.rj.def.br/uploads/arquivos/c2f0263c194e 4f67a218c75cfc9cf67e.pdf. Acesso em 28 set. 2019.

${ }^{34}$ CONSELHO NACIONAL DE JUSTIÇA. Departamento de Monitoramento e Fiscalização do Sistema Carcerário e do Sistema de Execução de Medidas Socioeducativas. Relatório de Gestão 2016/2018. Brasília: CNJ, 2018.

35 RIO DE JANEIRO (Estado). Secretaria de Administração Penitenciário do Estado do Rio de Janeiro. Consolidação Dados. Rio de Janeiro: SEAPRJ, 19 ago. 2019.

Revista Publicum

Rio de Janeiro, v. 6, n. 1, p. 42-69, 2020

http://www.e-publicacoes.uerj.br/index.php/publicum

DOI: $10.12957 /$ publicum.2020.56183 
Janeiro utiliza, no relatório do censo sistema prisional, os dados da SEAP ${ }^{36}$; 2) os relatórios da SEAP (de 2013 a agosto de 2019) são alimentados a partir do controle diário e presencial de entrada e saída dos presos, enquanto o CNJ utiliza dados obtidos pelo BNMP (Banco Nacional de Monitoramento de Prisões), cuja implantação no Rio de Janeiro somente iniciou-se em fevereiro de $2018^{37}$, e que depende da iniciativa de juízes e servidores na inserção dos mandados de prisão no sistema ${ }^{38}$; 3) os dados do Relatório Mensal do Cadastro Nacional de Inspeções nos Estabelecimentos Penais (CNIEP), divulgados pelo CNJ, aproximam-se dos dados fornecidos da SEAP39; e 4) finalmente, a Defensoria Pública do Rio de Janeiro, ao monitorar os resultados da audiência de custódia, também utiliza os dados da SEAP nos seus relatórios ${ }^{40}$.

Os dados da SEAP, ora utilizados, consideram como "presos provisórios" aqueles em relação aos quais não há sentença condenatória em primeira instância. Basta, portanto, a prolação de sentença em primeiro grau para que o preso não seja mais considerado provisório. Trata-se de um conceito mais restrito que a noção estritamente técnica de preso provisório, isto é, aquele sem condenação transitada em julgado. Assim, segundo a metodologia da SEAP, uma pessoa presa e já condenada em primeira instância, mesmo que por sentença ainda não transitada em julgado, não constitui um preso provisório.

Por razões idênticas, e para que se mantivesse a coerência na fonte de dados, em relação aos números nacionais, foram utilizadas as informações de Infopen (Levantamento Nacional de Informações Penitenciárias), divulgadas pelo DEPEN, um sistema alimentado pelos gestores dos estabelecimentos prisionais e não pelo CNJ, que utiliza os dados fornecidos pelos magistrados .

\footnotetext{
${ }^{36}$ TRIBUNAL DE JUSTIÇA DO ESTADO DO RIO DE JANEIRO. Grupo de Monitoramento e Fiscalização do Sistema Carcerário. Censo Sistema Prisional. Rio de Janeiro: TJRJ, 2019. Disponível em: http://gmf.tjrj.jus.br/censosistema-prisional. Acesso em 28 set. 2019.

${ }^{37}$ TJ do Rio vai se integrar ao banco de monitoramento de prisões do CNJ. Tribunal de Justiça do Estado do Rio de Janeiro, Rio de Janeiro, 6 fev. 2018. Disponível em: http://gmf.tjrj.jus.br/web/gmf/noticias/noticia//visualizar-conteudo/5265985/5278701. Acesso em 28 set. 2019.

$38 \mathrm{CNJ}$ lança mapa de implantação do cadastro nacional de presos. Tribunal de Justiça do Estado do Rio de Janeiro, Rio de Janeiro, 2 mar. 2018. Disponível em: http://gmf.tjrj.jus.br/web/gmf/noticias/noticia//visualizar-conteudo/5265985/5279006. Acesso em 28 set. 2019.

${ }^{39}$ No site http://www.cnj.jus.br/inspecao_penal/mapa.php, o CNJ divulga o número de presos atuais por unidade da federação, bem como a quantidade de vagas existentes.

40 O CNJ, por sua vez, defende a utilização do BNMP 2.0 como o meio de obtenção dos dados das pessoas presas no país: "Antes da implementação do BNMP 2.0, deixava-se a cargo da administração penitenciária dos estados a produção de informação sobre o número de presos, o que significava negligenciar parcela de responsabilidade do Poder Judiciário, precarizando a confiabilidade das estatísticas e dados que são relevantes para a definição da política penal e penitenciária. Ainda que instrumentos como levantamentos dos tribunais, o Geopresídios, e o Infopen constituíssem instrumentos relevantes para a compreensão da realidade penitenciária nacional, as diferenças dos quantitativos expressos em ambos os instrumentos reforçava a fragilidade desses bancos de dados". CONSELHO NACIONAL DE JUSTIÇA. Departamento de Monitoramento e Fiscalização do Sistema Carcerário e do Sistema de Execução de Medidas Socioeducativas. Relatório de Gestão 2016/2018. Brasília: CNJ, 2018.
} 


\section{Análise dos Resultados: um Estudo de Caso do Estado do Rio De} Janeiro

No Rio de Janeiro, em 18/9/2015, o Tribunal de Justiça aderiu ao Termo de Cooperação Técnica $\mathrm{n}^{\circ}$ 7/2015 e, em 24/8/2015, editou a Resolução TJ/OE/RJ n² 29/2015, para a disciplinar a audiência de custódia no âmbito do TJRJ e também enfrentar o "contingente desproporcional de pessoas presas provisoriamente no país".

Em 2011, no Rio de Janeiro, $35,64 \%^{41}$ dos presos eram provisórios. No ano seguinte, o percentual foi de $35,18 \%{ }^{42}$. Já em 2013 , há uma queda na proporção de presos provisórios para, em média ${ }^{43}, 29,94 \%$. A queda do percentual pode ser explicada pela entrada em vigor da Lei 12.403/2011, que possibilitou a aplicação, pelo juiz, de medidas alternativas à prisão processual com o fim de reduzir o número de presos provisórios no país, beneficiando os réus acusados de delitos para os quais a pena, ao final do processo, não seria privativa de liberdade ${ }^{44}$.

Interessante observar que essa redução não se reproduziu em âmbito nacional, pois, em 2011, a taxa de presos provisórios era de 33,8\%, e, após a Lei 12.403/2011, passou a ser, respectivamente de 35,5\% e 37,2\%, nos anos de 2012 e 2013. Em 2014, a referida taxa alcança o patamar histórico máximo, no período de 2000 a 2017, de 40,1\%.

Enquanto isso, no Rio de Janeiro, entre os anos de 2013 e 2017, a proporção dos presos provisórios manteria certa estabilidade, na seguinte sequência: 2013 - 29,94\%, 2014 - 29,96\%, 2015 - 30,22\%, 2016 - 29,82\%, e 2017 - 29,47\%.

\footnotetext{
${ }^{41}$ BRASIL. Departamento Penitenciário Nacional. Formulário Categoria e Indicadores Preenchidos: Rio de Janeiro-RJ. Brasília: DEPEN, dez. 2011.2 Disponível em: http://antigo.depen.gov.br/DEPEN/depen/sisdepen/infopen/relatorios-analiticos/RJ/rjdez2011.xls. Acesso em 28 set. 2019.

42 BRASIL. Departamento Penitenciário Nacional. Formulário Categoria e Indicadores Preenchidos: Rio de Janeiro-RJ. Brasília: DEPEN, 2012.2 dez. Disponível http://antigo.depen.gov.br/DEPEN/depen/sisdepen/infopen/relatorios-analiticos/RJ/rjdez2012.xls. Acesso em 28 set. 2019.

${ }^{43}$ A partir de 2013 , os dados utilizados foram os da SEAP, na forma de planilha semanal do quantitativo de presos. Por isso, foi utilizada a média no período anual, já que há pequenas variações, em razão das entradas e saídas dos presos ao longo do ano. RIO DE JANEIRO (Estado). Secretaria de Administração Penitenciário do Estado do Rio de Janeiro. Consolidação Dados. Rio de Janeiro: SEAPRJ, 19 ago. 2019.

44 Para uma análise mais detalhada, v. LEMGRUBER, Julita; FERNANDES, Márcia; CANO, Ignacio; MUSUMECI, Leonarda. Usos e abusos da prisão provisória no Rio de Janeiro: avaliação de impacto da Lei 12.403/2011 Rio de Janeiro: ARP/CESeC, 2013.
} 
Gráfico 3. Comparativo do percentual de presos provisórios: Brasil e RJ



Ainda que as variações sejam mínimas, é possível observar que a partir de setembro de 2015, quando as audiências de custódia são implementadas no Estado, inicialmente apenas na capital, há contínua queda do referido percentual.

No ano de 2017, quando já começa um processo mais vigoroso de expansão territorial das audiências de custódia no Estado, o percentual encontra o menor patamar entre 2013 e 2017, qual seja, $29,47 \%$.

Contudo, a maior redução ocorre de 2017 para 2018, quando as audiências de custódia passam a abranger todo o território do $\mathrm{Estado}^{45}$. Em 2018, a média de presos provisórios dentro do sistema prisional fluminense era de $27 \%$, uma redução de $2,47 \%$ em relação ao ano anterior.

A referida taxa manteve-se em queda até os dados colhidos neste trabalho (abril de 2019). A média de presos provisórios entre janeiro e abril de 2019 foi de 25,70\%.

A redução da referida taxa não significa que se está a encarcerar menos, pois os números absolutos revelam que cresce a quantidade de pessoas presas no Estado do Rio de Janeiro. No ano de 2013, a média anual ${ }^{46}$ de pessoas presas era de 33.802, enquanto que em 2018 já se alcançava 51.622 pessoas privadas de sua liberdade. Até abril de 2019, a média de pessoas encarceradas no

${ }^{45}$ RIO DE JANEIRO (Estado). Órgão Especial do Tribunal de Justiça. Resolução $n^{\circ}$ 14, de 16 out. 2017. Diário da Justiça Eletrônico do Estado do Rio de Janeiro: ADM: Poder Judiciário, n. 34, p. 18, 24 out. 2017.

${ }^{46} \mathrm{Em}$ razão do fluxo de saída e entrada de presos no sistema carcerário, o quantitativo anual deve observar uma data fixa ou média calculada no ano. Nesse caso, como os dados da SEAP obtidos são semanais, para obter-se um dado anual optou-se pelo cálculo operado pela média. 
Estado era de $52.284^{47}$.

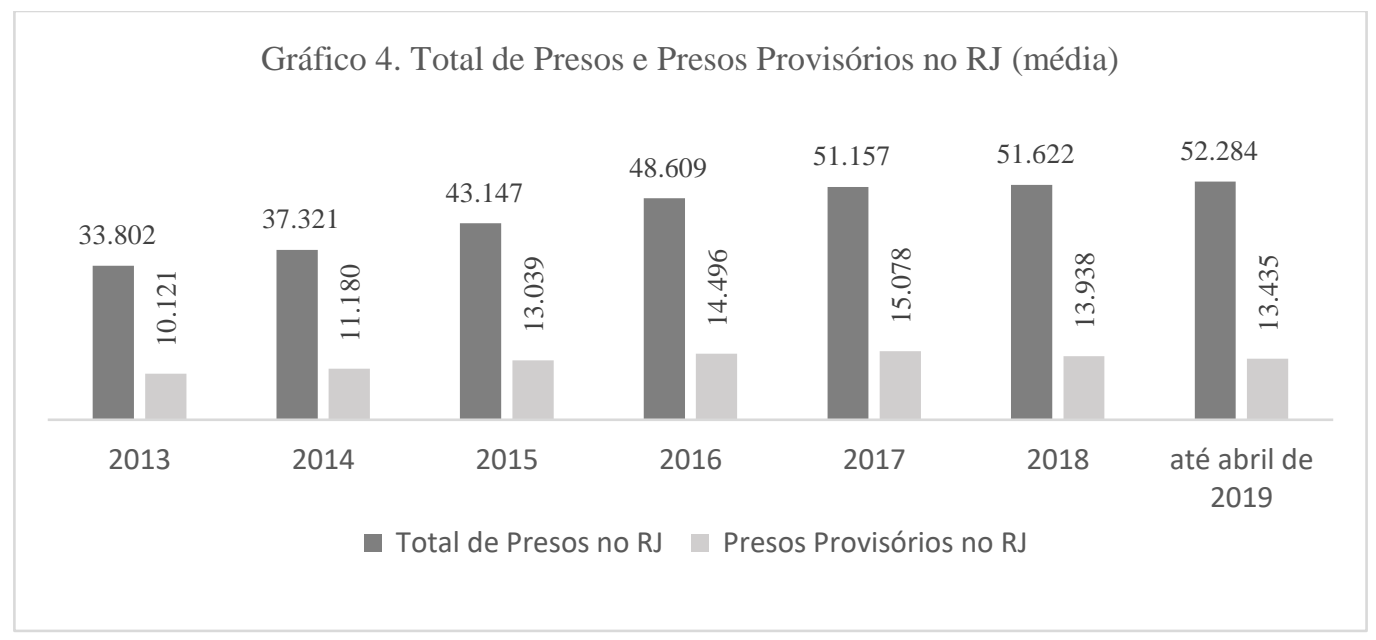

Mas, se por um lado há aumento do encarceramento, dado sobre o qual há a influência de uma variedade de fatores, é perceptível a redução proporcional de pessoas presas sem sentença condenatória (presos provisórios), intensificada após a expansão territorial das audiências de custódia pelo Estado. Em números absolutos, em 2015 havia 43.147 pessoas privadas de liberdade e, destas, 13.039 eram presos provisórios. Já em abril de 2019, o número de presos totais alcançou a quantia de 52.284 pessoas, enquanto o de presos provisórios se estabilizou em 13.435.

Portanto, se por um lado é certo dizer que as audiências de custódia produziram resultado positivo na redução da proporção de presos provisórios, por outro lado, não houve redução do encarceramento, nem mesmo do encarceramento cautelar. Em relação a este último, em verdade, houve apenas a estabilização do número em torno de 13 mil presos, enquanto o quantitativo de presos definitivos cresceu de 30.109 , em 2015, para 38.849, em abril de 2019, ou seja, um aumento de $29,02 \%$.

É possível imaginar que esse crescimento vertiginoso no número de presos definitivos no Estado tenha relação com a decisão do Plenário do Supremo Tribunal Federal, proferida em $17 / 2 / 2016$, quando do julgamento do Habeas Corpus $n^{\circ} 126.292^{48}$, e que permitiu a execução

${ }^{47}$ RIO DE JANEIRO (Estado). Secretaria de Administração Penitenciário do Estado do Rio de Janeiro. Consolidação Dados. Rio de Janeiro: SEAPRJ, 19 ago. 2019.

48 BRASIL. Supremo Tribunal Federal (Tribunal Pleno). Habeas Corpus 126292. CONSTITUCIONAL. HABEAS CORPUS. PRINCÍPIO CONSTITUCIONAL DA PRESUNÇÃO DE INOCÊNCIA (CF, ART. 5, LVII). SENTENÇA PENAL CONDENATÓRIA CONFIRMADA POR TRIBUNAL DE SEGUNDO GRAU DE JURISDIÇÃO. EXECUÇÃO PROVISÓRIA. POSSIBILIDADE. 1. A execução provisória de acórdão penal condenatório proferido em grau de apelação, ainda que sujeito a recurso especial ou extraordinário, não compromete o princípio constitucional da presunção de inocência afirmado pelo artigo 5o, inciso LVII da Constituição Federal. 2. Habeas corpus denegado. Relator: Min. Teori Zavascki, 17 fev. 2016. Diário da Justiça Eletrônico: 17 mai. 2016. 
provisória da pena, inclusive com recolhimento ao cárcere, antes do trânsito em julgado, mas após acórdão condenatório em segunda instância. A decisão foi confirmada em 5/10/2016, nos autos das medidas cautelares nas ações diretas de constitucionalidade $\mathrm{n}^{\circ} \mathrm{s} 43$ e $44^{49}$. Dada a metodologia da SEAP, que já considera definitivo o preso com sentença condenatória de primeiro grau ainda sujeita a recurso, a decisão do STF pode ter ocasionado um aumento no ingresso de presos considerados definitivos (com condenação em segunda instância, mesmo que não transitada em julgado), reduzindo, assim, o percentual de presos provisórios (sem sentença condenatória), pela diminuição da sua proporção em relação ao total de presos. De toda forma, a estabilização do número absoluto de presos provisórios (sem sentença condenatória) mostra o impacto da política pública das audiências de custódia - cujo âmbito de atuação é exatamente o dos presos provisórios -, especialmente quando verificada a tendência de crescimento dos presos provisórios em anos anteriores e o aumento de presos definitivos verificado até hoje. Cuida-se de um dado relevante, merecendo estudo e análise os impactos da referida decisão na situação carcerária no País, o que,

49 BRASIL. Supremo Tribunal Federal (Tribunal Pleno). Ação Direta Constitucionalidade 43 (Medida Cautelar). MEDIDA CAUTELAR NA AÇÃO DECLARATÓRIA DE CONSTITUCIONALIDADE. ART. 283 DO CÓDIGO DE PROCESSO PENAL. EXECUÇÃO DA PENA PRIVATIVA DE LIBERDADE APÓS O ESGOTAMENTO DO PRONUNCIAMENTO JUDICIAL EM SEGUNDO GRAU. COMPATIBILIDADE COM O PRINCÍPIO CONSTITUCIONAL DA PRESUNÇÃO DE INOCÊNCIA. ALTERAÇÃO DE ENTENDIMENTO DO SUPREMO TRIBUNAL FEDERAL NO JULGAMENTO DO HC 126.292. EFEITO MERAMENTE DEVOLUTIVO DOS RECURSOS EXTRAORDINÁRIOS E ESPECIAL. REGRA ESPECIAL ASSOCIADA À DISPOSIÇÃO GERAL DO ART. 283 DO CPP QUE CONDICIONA A EFICÁCIA DOS PROVIMENTOS JURISDICIONAIS CONDENATÓRIOS AO TRÂNSITO EM JULGADO. IRRETROATIVIDADE DA LEI PENAL MAIS GRAVOSA. INAPLICABILIDADE AOS PRECEDENTES JUDICIAIS. CONSTITUCIONALIDADE DO ART. 283 DO CÓDIGO DE PROCESSO PENAL. MEDIDA CAUTELAR INDEFERIDA. 1. No julgamento do Habeas Corpus 126.292/SP, a composição plenária do Supremo Tribunal Federal retomou orientação antes predominante na Corte e assentou a tese segundo a qual "A execução provisória de acórdão penal condenatório proferido em grau de apelação, ainda que sujeito a recurso especial ou extraordinário, não compromete o princípio constitucional da presunção de inocência afirmado pelo artigo 5o, inciso LVII da Constituição Federal". 2. No âmbito criminal, a possibilidade de atribuição de efeito suspensivo aos recursos extraordinário e especial detém caráter excepcional (art. 995 e art. 1.029, §5, ambos do CPC c/c art. 3ํ e 637 do (PP), normativa compatível com a regra do art. 5ํ, LVII, da Constituição da República. Efetivamente, o acesso individual às instâncias extraordinárias visa a propiciar a esta Suprema Corte e ao Superior Tribunal de Justiça exercer seus papéis de estabilizadores, uniformizadores e pacificadores da interpretação das normas constitucionais e do direito infraconstitucional. 3. Inexiste antinomia entre a especial regra que confere eficácia imediata aos acórdãos somente atacáveis pela via dos recursos excepcionais e a disposição geral que exige o trânsito em julgado como pressuposto para a produção de efeitos da prisão decorrente de sentença condenatória a que alude o art. 283 do CPP. 4 . O retorno à compreensão emanada anteriormente pelo Supremo Tribunal Federal, no sentido de conferir efeito paralisante a absolutamente todas decisões colegiadas prolatadas em segundo grau de jurisdição, investindo os Tribunais Superiores em terceiro e quarto graus, revela-se inapropriado com as competências atribuídas constitucionalmente às Cortes de cúpula. 5 . A irretroatividade figura como matéria atrelada à aplicação da lei penal no tempo, ato normativo idôneo a inovar a ordem jurídica, descabendo atribuir ultratividade a compreensões jurisprudenciais cujo objeto não tenha reflexo na compreensão da ilicitude das condutas. Na espécie, o debate cinge-se ao plano processual, sem reflexo, direto, na existência ou intensidade do direito de punir, mas, tão somente, no momento de punir. 6. Declaração de constitucionalidade do art. 283 do Código de Processo Penal, com interpretação conforme à Constituição, assentando que é coerente com a Constituição o principiar de execução criminal quando houver condenação assentada em segundo grau de jurisdição, salvo atribuição expressa de efeito suspensivo ao recurso cabível. 7. Medida cautelar indeferida. Relator: Min. Marco Aurélio, Relator p/ Acórdão: Min. Edson Fachin, 05 out. 2016. Diário da Justiça Eletrônico: 07 mar. 2018.

Revista Publicum

Rio de Janeiro, v. 6, n. 1, p. 42-69, 2020

http://www.e-publicacoes.uerj.br/index.php/publicum

DOI: $10.12957 /$ publicum.2020.56183 
porém, não cabe nesse espaço, em razão dos limites estabelecidos para o tema.

Com efeito, a audiência de custódia pode ter apenas desacelerado um pouco o crescimento da população carcerária no Estado do Rio de Janeiro, por seu impacto de estabilização do número de presos provisórios e redução da sua proporcionalidade no sistema como um todo. Entre 2011 e 2014, a taxa de crescimento da população prisional local era de 8,37\%. Mantido o mesmo ritmo até abril de 2019, teríamos hoje 60.748 presos, ou seja, 8.464 a mais que os atuais 52.284 .

Mas é inegável que o número de presos totais continuou a crescer numa taxa anual média ainda expressiva, de 7,14\% entre 2015 e agosto de 2019. Isso significa que, mesmo com as audiências de custódia, o sistema carcerário continua superlotado, numa taxa de ocupação de $187,66 \%$, já que possui 28.525 vagas para 53.531 presos $^{50}$.

Portanto, no Rio de Janeiro, é possível que as audiências de custódia tenham apenas mitigado um pouco o crescimento do superencarceramento, que continua a crescer em taxa um pouco menor do que vinha ocorrendo nos anos anteriores (de 8,37\% entre 2011 e 2014 para 7,14\% de 2015 a 2019). Isso significa que o estado de superlotação do sistema não foi alterado e continua a se agravar. Assim, quase nada mudou no quadro das massivas violações aos direitos fundamentais das pessoas privadas de liberdade, a permanecer o estado de coisas inconstitucional ${ }^{51}$.

Além disso, outro dado merece atenção: os juízes têm proferido cada vez menos decisões de soltura nas audiências de custódia desde sua implantação. A média percentual das decisões nesse sentido, em 2015, era de 47\%. Nos anos de 2016 e 2017, por sua vez, as decisões de liberdade representavam, respectivamente, 37\% e 40\%. Mas já em 2018 e 2019, a referida taxa diminui para $26 \%$, em média, em ambos os períodos ${ }^{52}$.

50 RIO DE JANEIRO (Estado). Secretaria de Administração Penitenciário do Estado do Rio de Janeiro. Consolidação Dados. Rio de Janeiro: SEAPRJ, 19 ago. 2019.

${ }^{51} \mathrm{Em}$ 22/11/2018, a Corte Interamericana de Direitos Humanos reconheceu o estado de coisas contrário à Constituição no Instituto Penal Plácido de Sá Carvalho, localizado no Estado do Rio de Janeiro, e impôs algumas medidas, destacando-se a seguinte: “O Estado deverá arbitrar os meios para que, no prazo de seis meses a contar da presente decisão, se compute em dobro cada dia de privação de liberdade cumprido no IPPSC, para todas as pessoas ali alojadas, que não sejam acusadas de crimes contra a vida ou a integridade física, ou de crimes sexuais, ou não tenham sido por eles condenadas, nos termos dos Considerandos 115 a 130 da presente resolução". CORTE INTERAMERICANA DE DIREITOS HUMANOS. Resolução de 22 de novembro de 2018: Assunto do Instituto Penal Plácido de Sá Carvalho. Medidas provisórias a respeito do Brasil. São José, Costa Rica: Corte IDH, 2018. Disponível em: https://www.corteidh.or.cr/docs/medidas/placido_se_03_por.pdf. Acesso em 28 set. 2019.

52 DEFENSORIA PÚBLICA DO ESTADO DO RIO DE JANEIRO. Planilha Resultado Audiência de Custódia. Rio de Janeiro: DPERJ, 2019. 


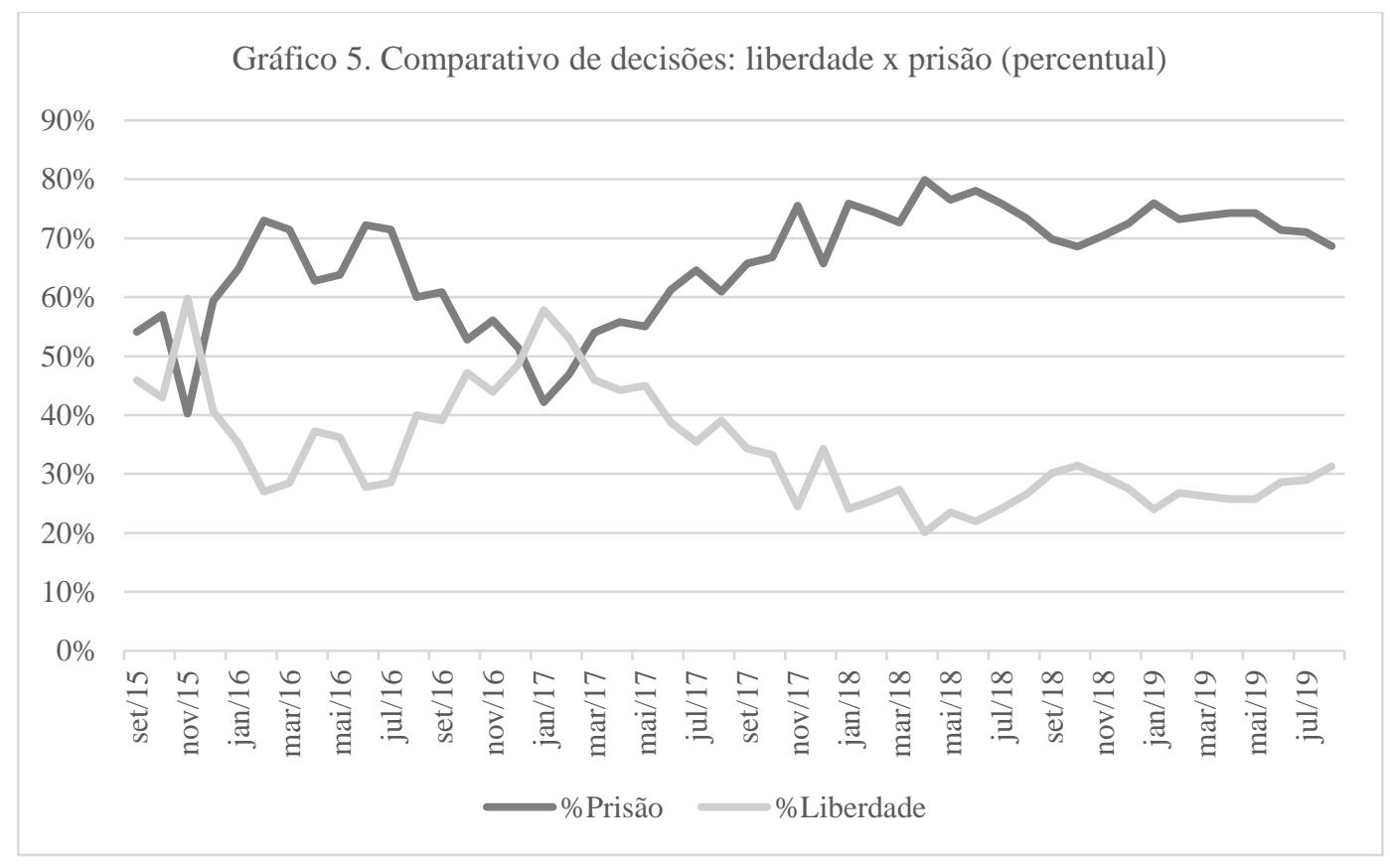

Deve ser observado que, em âmbito nacional, até junho de 2017, segundo o CNJ, do total de 258.485 audiências de custódia realizadas, 115.497 casos resultaram em liberdade, o que revela um percentual de soltura de $44,68 \%^{53}$.

Não há um motivo claro para essa drástica redução no percentual de casos com liberdade concedida a partir de 2018, no Estado do Rio de Janeiro, mas um dado merece atenção: o comportamento dos juízes dentro de uma cultura de encarceramento.

Como a decisão de concessão de liberdade é ato jurisdicional dotado de larga discricionariedade, pode haver uma sensível diferença no número de decisões concessivas de liberdade por cada juiz.

Em São Paulo, numa análise de 346 decisões proferidas por 11 juízes, foi possível perceber que, entre os magistrados, o percentual das decisões de liberdade variava de $50 \%$ até $70 \%$, a depender do juiz ${ }^{54}$. Já no Rio de Janeiro, nos dois primeiros anos de implantação da audiência de custódia, os 18 juízes que atuaram proferiram decisões concessivas de liberdade que variaram de

53 CONSELHO NACIONAL DE JUSTIÇA. Dados Estatísticos/Mapa de Implantação. Brasília: CNJ, 2017. Disponível em: https://www.cnj.jus.br/sistema-carcerario/mapa-audiencia-de-custodia/. Acesso em 28 set. 2019.

${ }^{54}$ CONSELHO NACIONAL DE JUSTIÇA. Relatório Analítico Propositivo: Justiça Pesquisa. Direitos e garantias fundamentais: audiência de custódia, prisão provisória e medidas cautelares: obstáculos institucionais e ideológicos à efetivação da liberdade como regra. Brasília: CNJ, 2018, p. 96. Disponível em: https://forumseguranca.org.br/wpcontent/uploads/2018/10/FBSP_Direitos_Garantias_Fundamentais_CNJ_2018.pdf. Acesso em 28 set. 2019.

Revista Publicum

Rio de Janeiro, v. 6, n. 1, p. 42-69, 2020

http://www.e-publicacoes.uerj.br/index.php/publicum

DOI: $10.12957 /$ publicum. 2020.56183 
$18 \%$ a $55,3 \%$, a depender do magistrado ${ }^{55}$.

Outra mudança observada no Rio de Janeiro é que, a partir de março de 2018, as audiências de custódia foram realizadas quase sempre por juízes regionais, com recente ingresso na carreira, um quadro diferente daquele que se apresentava nos 2 (dois) primeiros anos de sua implantação ${ }^{56}$.

Com efeito, a Lei Orgânica da Magistratura (LC 35/1979), ao prever as garantias funcionais para a livre decisão dos juízes, não diferencia os membros mais novos dos mais antigos na carreira. Mas é inegável que, quando as audiências de custódia eram predominantemente realizadas por juízes mais antigos, o percentual de decisões concessivas de liberdade chegou a picos de $60 \%$ (novembro/2015) e 58\% (janeiro/2017). Quando o corpo de magistrados passou a ser majoritariamente formado por membros mais novos na carreira, esse percentual máximo não ultrapassou $31 \%$.

Portanto, o perfil dos magistrados pode alterar, de forma sensível, o quantitativo de pessoas libertadas nas audiências de custódia. E, se considerarmos que há uma persistência da cultura do encarceramento ${ }^{57}$ como principal forma de solução dos problemas de segurança pública, há sério risco de refluxo dos resultados obtidos com as audiências de custódia na redução dos presos provisórios do país.

Não é à toa que o então coordenador do curso de audiência de custódia para magistrados, o juiz Marcelo Oliveira da Silva, alertou: "Ainda existe uma cultura de encarceramento muito arraigada. Nós temos um Código de Processo Penal de 1945. Há uma cultura de encarceramento como solução para a criminalidade, ao passo que esse é um problema social" ${ }^{\prime 58}$.

55 DEFENSORIA PÚBLICA DO ESTADO DO RIO DE JANEIRO. Relatório 2o ano das audiências de custódia no Rio de Janeiro. Rio de Janeiro: DPERJ, 2018. Disponível em http://www.defensoria.rj.def.br/uploads/arquivos/c2f0263c194e 4f67a218c75cfc9cf67e.pdf. Acesso em 28 set. 2019.

${ }^{56}$ A informação de que, a partir de março de 2018, as audiências de custódia passaram a ser realizadas quase sempre por juízes regionais, foi obtida com a conjugação de dados colhidos no Caderno I - Administrativo, do Diário da Justiça Eletrônico (https://www3.tjrj.jus.br/consultadje/), onde são publicadas as portarias de designação dos juízes feitas pelo Presidente do Tribunal de Justiça, com a lista de antiguidade dos magistrados disponibilizada no site da $\quad$ Corte estadual (http://www.tjrj.jus.br/web/guest/consultas/magistrados/magistrados).

${ }^{57}$ A cultura do encarceramento na magistratura foi reconhecida pelo então Presidente do STF e do CNJ, Ricardo Lewandowski, em discurso proferido por ocasião do lançamento do Anuário da Justiça em 14/4/2015. LEWANDOWSKI e Marco Aurélio criticam escalada do punitivismo no Brasil. CONJUR, São Paulo, 26 abr. 2015, 14:52. Disponível em: https://www.conjur.com.br/2015-abr-26/juizes-discursam-durante-lancamentoanuario-justica-brasil. Acesso em 28 set. 2019.

58 'HÁ uma cultura de encarceramento', diz coordenador do curso de audiência de custódia, Tribunal de Justiça do Estado do Rio de Janeiro, Rio de Janeiro, 5 mar. 2018. Disponível em: http://gmf.tjr.jus.br/web/gmf/noticias/noticia/-/visualizar-conteudo/5265985/5279183. Acesso em 28 set. 2019. Contudo, não concordamos com a declaração do magistrado de que a criminalidade decorra de um problema social. A questão é complexa e, no Brasil, é imprescindível que se faça uma abordagem transversal a partir do racismo estrutural, elemento central na distribuição de bens e direitos no país. Ver neste sentido: ALMEIDA, Silvio de. 0 que é racismo estrutural. Belo Horizonte: Editora Letramento, 2018; BORGES, Juliana. Encarceramento em massa. São Paulo: Polén, 2019; e SINHORETO, Jacqueline; LIMA, Renato Sérgio de. 
O curso, promovido pelo TJRJ, contava com a participação de expositores de várias áreas do conhecimento e está previsto no inciso II do artigo $9^{\circ}$ da Resolução TJ/OE/RJ n 29/2015 ${ }^{59}$, como um dos requisitos para a designação, pelo Presidente do Tribunal, dos magistrados atuantes nas audiências de custódia. $O$ outro requisito é que os juízes tenham atuado em varas com competência criminal por pelo menos 6 (seis) meses.

Além disso, a referida resolução prevê a publicação de editais de seleção, permitindo-se que os magistrados, desde que atendidos os requisitos acima, manifestem seu interesse em atuar nas audiências de custódia. A designação dos juízes fica a cargo do Presidente do Tribunal, que deve escolhê-los, preferencialmente, dentre aqueles inscritos pelo edital e que cumpram os requisitos da Resolução.

Ocorre que, desde março de 2018, o mencionado curso deixou de ser ministrado e não mais foram publicados os editais de inscrição, passando a designação a ser feita por livre escolha do Presidente do Tribunal de Justiça ${ }^{60}$. Tal data (março de 2018) coincide com o momento no qual, como indicado acima, as audiências de custódia passaram a ser realizadas predominantemente por juízes regionais, com recente ingresso na carreira, e no qual também o percentual de decisões concessivas de liberdade não ultrapassou $31 \%$.

Essas informações indicam que o comportamento dos juízes num contexto de cultura do encarceramento pode ser um obstáculo que precisa ser superado para a efetividade das audiências de custódia como política pública redução dos números de presos provisórios no Brasil. A solução é complexa, mas o retorno dos editais de inscrição, conforme a Resolução TJ/OE/RJ n 35/2015, bem como a retomada do curso multidisciplinar ministrado até março de 2018, pode ser um pontapé inicial.

Narrativa autoritária e pressões democráticas na segurança pública e no controle do crime. Contemporânea - Revista de Sociologia da UFSCar, Salvador, v. 5, n. 1, p. 119-141, jan./jun. 2015.

59 RIO DE JANEIRO (Estado). Órgão Especial do Tribunal de Justiça. Resolução $n^{\circ} 29$, de 24 ago. 2015. Diário da Justiça Eletrônico do Estado do Rio de Janeiro: ADM: Poder Judiciário, n. 8, p. 20, 11 nov. 2015. Art. 9o Caberá ao Presidente do Tribunal de Justiça designar os Juízes de Direito que atuarão na Central de Audiência de Custódia, com ou sem afastamento das suas funções, recaindo a escolha, preferencialmente, dentre os que preencham os seguintes requisitos: I - Juízes Titulares ou Regionais com competência criminal, há pelo menos 6 (seis) meses, excluindo-se os de competência de Execuções Penais e Juizado Especial Criminal; II Juízes que tenham participação regular em curso de capacitação específico ministrado pela EMERJ, que terá validade de 1 (um) ano. § 1 - O Tribunal de Justiça publicará edital de seleção dos Juízes que atuarão nas CEAC's, indicando o número de vagas, conforme a necessidade de cada Comarca. § 2 o - A designação de que trata o caput terá a duração de 4 (quatro) meses, podendo haver a recondução, a critério da Presidência. § 30 Poderá ser designado, também pelo Presidente do Tribunal, um Juiz Coordenador da CEAC, a quem competirá a gestão da serventia.

60 Essa informação foi obtida com a análise das publicações do Tribunal de Justiça no Diário da Justiça Eletrônico (https://www3.tjrj.jus.br/consultadje/). 


\section{A Cultura do Encarceramento: Um Obstáculo aos Objetivos de}

\section{Redução dos Presos Provisórios por Meio das Audiências de Custódia}

Apesar de já possuir a terceira maior população prisional no mundo em números absolutos e uma taxa de crescimento de encarceramento ${ }^{61}$ que, se projetada, resultará num contingente de 1.471.013 presos em 2025, muitos ainda discordam que no Brasil se prende muito. Dentre eles, autoridades como o atual Diretor de Departamento Penitenciário Nacional (DEPEN), Fabiano Bordignon, que afirmou em entrevista para a imprensa, em 22/9/2019: “a quantidade não é importante. Temos os presos que merecemos ter, que nosso momento histórico permite" ${ }^{\prime 62}$.

Durante o trâmite do Projeto de Lei $n^{\circ}$ 554/2011, no Senado Federal, que pretende inserir o procedimento da audiência de custódia no Código de Processo Penal (CPP), algumas falas de instituições de segurança pública e da administração da justiça revelaram a disseminação dessa cultura de encarceramento que pode obstaculizar políticas públicas de redução do quantitativo de presos no Brasil. Dentre estas, destacam-se as seguintes:

a liberação de acusados causará sensação de insegurança na sociedade, além de reforçar o
sentimento de impunidade na população, que vai desacreditar o trabalho da polícia, já que a pessoa que é presa será colocada imediatamente em liberdade ${ }^{63}$.

Assim, todo preso irá alegar perante o Juiz que foi torturado na rua para tornar nula a prisão e ser solto. E o policial responsável pela prisão, em decorrência das declarações do preso, irá responder injustamente pelo crime de tortura, anos a fio, podendo até mesmo ser preso em flagrante pelo Juiz, passando de condutor a preso e o preso, de criminoso a vítima. Numa total e absurda inversão de valores.

Isso fará com que os policiais deixem de agir, preferindo correr o risco de responder pelo crime de prevaricação a responder por tortura, crime inafiançável de graça ou anistia, segundo o disposto no inciso XLIII, do artigo $5^{\circ}$ da Constituição Federal.

E a criminalidade crescerá substancialmente, pois poucos policiais se arriscarão a prender um criminoso em flagrante delito.

Na realidade, o único beneficiário da Lei será o marginal, em prejuízo dos elevados interesses do cidadão de bem, que ficará ainda mais desprotegido ${ }^{64}$.

Se é certo que as prisões cautelares são excepcionais no atual ambiente jurídico nacional e que a violência policial e tortura são comportamentos altamente censuráveis e ilegítimos, não é possível a adoção de expedientes tendentes ao maior grau de embaraço da efetiva aplicação da lei penal em face da aguda sensação de impunidade e de insegurança geral e da

${ }^{61}$ Com base na média de 8,30\% ao ano, calculada pelo Ministério da Segurança Pública. V. BRASIL. Ministério da Segurança Pública. Apresentação Diagnóstico MSP. Brasília: MSP, 2019. Disponível em: https://www.justica.gov.br/news/copy_of_collective-nitf-content-26/apresentacao-diagnostico-msp.pdf. Acesso em 28 set. 2019.

62 MARIZ, Renata. Diretor-Geral penitenciário diz que país precisa de 20 mil a 25 mil vagas por ano para resolver o déficit. Jornal O Globo, Rio de Janeiro, 22 set. 2019. Disponível em: <https://glo.bo/2LC6QLd>. Acesso em: 29 set.2019.

${ }^{63}$ ASSOCIAÇÃO NACIONAL DOS DELEGADOS DE POLÍCIA FEDERAL. Nota técnica ao Projeto de Lei do Senado $\mathbf{n}^{\circ}$ 554, de 2011. Brasília: ADEPOL, 5 ago. 2014.

64 FEDERAÇÃO NACIONAL DOS DELEGADOS DE POLÍCIA FEDERAL. Ofício $\mathbf{n}^{\circ}$ 37/14-FENADEPOL. Ref.: PLS 554/2011. Brasília: FENADEPOL, 4 ago. 2014.

Revista Publicum

Rio de Janeiro, v. 6, n. 1, p. 42-69, 2020

http://www.e-publicacoes.uerj.br/index.php/publicum

DOI: $10.12957 /$ publicum.2020.56183 
capilaridade da criminalidade organizada, tendo em vista que o ordenamento jurídico pátrio conta com mecanismos que beneficiam autores de delitos graves e hediondos ${ }^{65}$.

Vale ressaltar que, ainda que se admita a existência de violações pontuais à integridade do preso em flagrante, é de se supor que poucos relatariam isso por ocasião da proposta audiência de custódia, ainda mais tendo o preso ciência de que, depois da audiência, retornará ao sistema prisional, onde poderá sofrer represálias ${ }^{66}$

Em pesquisa promovida pela Associação dos Magistrados Brasileiros, parcela significativa dos juízes de primeira instância demonstrou resistência à implementação das audiências de custódia:

Sobre a justiça criminal, uma bateria de questões (33 à 38) solicita que o respondente manifeste seu grau de concordância com algumas assertivas. Entre os juízes de 10 grau, mais de $90 \%$ concordam pouco ou muito com as seguintes afirmações: 'o sistema penitenciário deve aplicar metodologias de valorização humana'; 'o sistema de vídeo conferência para realização de interrogatório e instrução do processo deve ser integrado ao sistema processual penal'; e 'as medidas cautelares, no âmbito criminal, somente podem ser aplicadas pelo(a) magistrado(a)'. A única assertiva que não contou com adesão tão esmagadora quanto as anteriores, restringindo-se a $50 \%$ dos juízes, é a de que 'a audiência de custódia é um importante mecanismo de garantia processual do acusado e deve ser aperfeiçoada'. Entre os juízes de $2^{\circ}$ grau, contudo, a concordância com essa assertiva é bem superior: cerca de $80 \%{ }^{67}$

Desta feita, políticas públicas de redução do número de presos, para o enfrentamento dos problemas superlotação do sistema prisional e violações dos direitos fundamentais das pessoas presas no país, devem necessariamente reconhecer a cultura do encarceramento disseminada entre órgãos de segurança pública e de justiça, sobretudo que atuam na primeira instância, como obstáculo a sua efetividade. Tal é imprescindível para a escolha de novos meios de implementação da política pública, evitando-se soluções que demandem avaliações e decisões discricionárias desses agentes do sistema jurídico. Um exemplo seria a determinação pelo Supremo Tribunal Federal, nos autos da ADPF 347, de contagem em dobro cada dia de privação de liberdade para os encarcerados em presídios cuja lotação supere os $100 \%$, a exemplo da decisão da Corte Interamericana de Direitos Humanos no que tange ao Instituto Penal Plácido de Sá Carvalho, no Estado do Rio de Janeiro ${ }^{68}$.

65 ASSOCIAÇÃO NACIONAL DOS MEMBROS DO MINISTÉRIO PÚBLICO. Ofício nº 029/2015-GAB/CONAMP. Brasília: CONAMP, 19 fev. 2015.

${ }^{66}$ ASSOCIAÇÃO DOS JUÍZES FEDERAIS DO BRASIL. Nota Técnica ${ }^{\circ}$ 16/2014 Assunto: PLS n 554/2011. Brasília: AJUFE, 4 dez. 2014.

67 VIANNA, Luiz Werneck; CARVALHO, Maria Alice Rezende de; BURGOS, Marcelo Baumann. Quem somos: a magistratura que queremos. Rio de Janeiro: Associação dos Magistrados Brasileiros, 2018, p. 38.

68 CORTE INTERAMERICANA DE DIREITOS HUMANOS. Resolução de 22 de novembro de 2018: Assunto do Instituto Penal Plácido de Sá Carvalho. Medidas provisórias a respeito do Brasil. São José, Costa Rica: Corte IDH, 2018. Disponível em: https://www.corteidh.or.cr/docs/medidas/placido_se_03_por.pdf. Acesso em 28 set. 2019. 


\section{Conclusão}

A audiência de custódia é direito de toda presa no Brasil, por decorrer da aplicação de normas internacionais de direitos humanos (Pacto Internacional sobre Direitos Civis e Políticos e a Convenção Americana sobre Direitos Humanos). E, se por um lado, no seu nascedouro, foi concebida como uma política pública de enfrentamento do quadro de superencarceramento no sistema prisional do País, sua força cogente independe de qualquer resultado nesse sentido.

De qualquer forma, os dados apresentados demonstram que as audiências de custódia têm o potencial efeito de desacelerar, ainda que de forma tímida, o incremento da população prisional, sobretudo dos presos provisórios. E se elas não foram capazes de reduzir o número absoluto de presos, mas apenas de diminuir a taxa de seu crescimento, isso se deu porque se trata de um instrumento que depende do comportamento dos juízes, imersos numa cultura de encarceramento que se apresenta como um obstáculo à efetividade da política pública.

Evidentemente, tal conclusão não deve resultar no abandono da política pública para superação do estado de coisas inconstitucional no sistema prisional brasileiro. Além do esforço de expansão para todo território nacional e para toda pessoa que venha a ser privada de sua liberdade, os gestores dessa política pública devem considerar a necessidade de implementar programas educacionais, como o que ocorria no TJRJ, que possam conscientizar juízes e promotores da imprescindibilidade de redução do uso da prisão cautelar nos processos criminais, sobretudo no que tange a delitos cuja eventual condenação não resultará numa pena privativa de liberdade.

Além disso, a experiência fluminense demonstra que a adoção de modelos de escolha direta e meramente discricionária, pelo Presidente do Tribunal de Justiça, dos juízes que devem atuar nas audiências de custódia, parece reduzir o número de decisões concessivas de liberdade.

De qualquer forma, faz-se urgente uma política pública de desencarceramento que promova de forma mais ampla e efetiva a redução do número de pessoas no sistema prisional do País. Por isso, outras medidas devem ser implementadas, preferencialmente que não dependam, de forma exclusiva, de decisões judiciais a serem proferidas, sobretudo, por juízes de primeira instância, já que dentre estes há, como dito, uma disseminada cultura de encarceramento.

Uma solução seria, por exemplo, a contagem em dobro para cada dia de privação de liberdade em favor dos encarcerados em presídios cuja lotação supere os $100 \%$, a exemplo da decisão da Corte Interamericana de Direitos Humanos no que tange ao Instituto Penal Plácido de Sá Carvalho, no Estado do Rio de Janeiro. 


\section{Referências}

'HÁ uma cultura de encarceramento', diz coordenador do curso de audiência de custódia, Tribunal de Justiça do Estado do Rio de Janeiro, Rio de Janeiro, 5 mar. 2018. Disponível em: http://gmf.tjrj.jus.br/web/gmf/noticias/noticia/-/visualizar-conteudo/5265985/5279183. Acesso em 28 set. 2019.

ALMEIDA, Silvio de. O que é racismo estrutural. Belo Horizonte: Editora Letramento, 2018.

ASSOCIAÇÃO DOS DELEGADOS DE POLÍCIA DO BRASIL. Nota técnica ao Projeto de Lei do Senado $n^{\circ}$ 554, de 2011. Brasília: ADEPOL, 5 ago. 2014.

ASSOCIAÇÃO DOS JUÍZES FEDERAIS DO BRASIL. Nota Técnica $n^{\circ}$ 16/2014 Assunto: PLS $n^{\circ}$ 554/2011. Brasília: AJUFE, 4 dez. 2014.

ASSOCIAÇÃO NACIONAL DOS DELEGADOS DE POLíCIA FEDERAL. Nota técnica ao Projeto de Lei do Senado ${ }^{\circ}$ 554, de 2011. Brasília: ADEPOL, 5 ago. 2014.

ASSOCIAÇÃO NACIONAL DOS MEMBROS DO MINISTÉRIO PÚBLICO. Ofício n 029/2015GAB/CONAMP. Brasília: CONAMP, 19 fev. 2015.

BARCELLOS, Ana Paula de. Políticas públicas e o dever de monitoramento: "levando os direitos a sério”. Revista Brasileira de Políticas Públicas, Brasília, v. 8, n. 2, p. 251-265, 2018.

BORGES, Juliana. Encarceramento em massa. São Paulo: Polén, 2019.

BRASIL. Decreto 592, de 6 de julho de 1992. Atos Internacionais. Pacto Internacional sobre Direitos Civis e Políticos. Promulgação. Diário Oficial da União: seção 1, Brasília, DF, p. 8716, 7 jul. 1992.

BRASIL. Decreto 678, de 6 de novembro de 1992. Promulga a Convenção Americana sobre Direitos Humanos (Pacto de São José da Costa Rica), de 22 de novembro de 1969. Diário Oficial da União: seção 1, Brasília, DF, p. 15562, 9 nov. 1992.

BRASIL. Departamento Penitenciário Nacional; CONSELHO NACIONAL DE JUSTIÇA. Termo de Execução Descentralizada n. 010/2018. Dispõe sobre o desenvolvimento de estratégias para promover a redução da superlotação e superpopulação carcerária no Brasil, com enfoque nas políticas de alternativas penais e monitoração eletrônica de pessoas. Diário Oficial da União: seção 3, Brasília, DF, p. 125, 24 out. 2018.

BRASIL. Departamento Penitenciário Nacional. Formulário Categoria e Indicadores Preenchidos: Rio de Janeiro-RJ. Brasília: DEPEN, dez. 2011. Disponível em:

http://antigo.depen.gov.br/DEPEN/depen/sisdepen/infopen/relatoriosanaliticos/RJ/rjdez2011.xls. Acesso em 28 set. 2019.

BRASIL. Departamento Penitenciário Nacional. Levantamento nacional de informações penitenciárias: atualização junho de 2017. Brasília: DEPEN, 2019. 
BRASIL. Departamento Penitenciário Nacional. Levantamento nacional de informações penitenciárias. Brasília: DEPEN, 2015.

BRASIL. Instituto Brasileiro de Geografia e Estatística. Brasil em síntese. Brasília: IBGE, 2019. Disponível em: https://brasilemsintese.ibge.gov.br/populacao/populacao-total-1980-2010.html. Acesso em 28 set. 2019.

BRASIL. Ministério da Segurança Pública. Apresentação Diagnóstico MSP. Brasília: MSP, 2019. Disponível em: https://www.justica.gov.br/news/copy_of_collective-nitf-content26/apresentacao-diagnostico-msp.pdf. Acesso em 28 set. 2019.

BRASIL. Supremo Tribunal Federal (Tribunal Pleno). Ação Direta Constitucionalidade 43 (Medida Cautelar). Relator: Min. Marco Aurélio, Relator p/ Acórdão: Min. Edson Fachin, 05 out. 2016. Diário da Justiça Eletrônico: 07 mar. 2018.

BRASIL. Supremo Tribunal Federal (Tribunal Pleno). Ação Direta de Inconstitucionalidade 5240/DF. Relator: Min. Luiz Fux, 20 ago. 2015. Diário da Justiça Eletrônico: 1o fev. 2016.

BRASIL. Supremo Tribunal Federal (Tribunal Pleno). Arguição de Descumprimento de Preceito Fundamental 347 (Medida Cautelar). Relator: Min. Marco Aurélio, 9 set. 2015. Diário da Justiça Eletrônico: 19 fev. 2016.

BRASIL. Supremo Tribunal Federal (Tribunal Pleno). Habeas Corpus 126292. Relator: Min. Teori Zavascki, 17 fev. 2016. Diário da Justiça Eletrônico: 17 mai. 2016.

CÂMARA DOS DEPUTADOS (Brasil). Relatório final da Comissão Parlamentar de Inquérito do Sistema Carcerário. Brasília: Câmara dos Deputados, 2009.

CNJ lança mapa de implantação do cadastro nacional de presos. Tribunal de Justiça do Estado do Rio de Janeiro, Rio de Janeiro, 2 mar. 2018. Disponível em:

http://gmf.tjrj.jus.br/web/gmf/noticias/noticia/-/visualizar-conteudo/5265985/5279006. Acesso em 28 set. 2019.

CONSELHO NACIONAL DE JUSTIÇA. Dados Estatísticos/Mapa de Implantação. Brasília: CNJ, 2017. Disponível em: https://www.cnj.jus.br/sistema-carcerario/mapa-audiencia-de-custodia/. Acesso em 28 set. 2019.

CONSELHO NACIONAL DE JUSTIÇA. Departamento de Monitoramento e Fiscalização do Sistema Carcerário e do Sistema de Execução de Medidas Socioeducativas. Relatório de Gestão 2016/2018. Brasília: CNJ, 2018.

CONSELHO NACIONAL DE JUSTIÇA. Relatório Analítico Propositivo: Justiça Pesquisa. Direitos e garantias fundamentais: audiência de custódia, prisão provisória e medidas cautelares: obstáculos institucionais e ideológicos à efetivação da liberdade como regra. Brasília: CNJ, 2018. Disponível em: https://forumseguranca.org.br/wp-

content/uploads/2018/10/FBSP_Direitos_Garantias_Fundamentais_CNJ_2018.pdf. Acesso em 28 set. 2019.

CORTE INTERAMERICANA DE DIREITOS HUMANOS. Resolução de 22 de novembro de 2018:

Assunto do Instituto Penal Plácido de Sá Carvalho. Medidas provisórias a respeito do Brasil. São 
José, Costa Rica: Corte IDH, 2018. Disponível em:

https://www.corteidh.or.cr/docs/medidas/placido_se_03_por.pdf. Acesso em 28 set. 2019.

DEFENSORIA PÚBLICA DO ESTADO DO RIO DE JANEIRO. Planilha Resultado Audiência de

Custódia. Rio de Janeiro: DPERJ, 2019.

DEFENSORIA PÚBLICA DO ESTADO DO RIO DE JANEIRO. Relatório 2 ano das audiências de custódia no Rio de Janeiro. Rio de Janeiro: DPERJ, 2018. Disponível em

http://www.defensoria.rj.def.br/uploads/arquivos/c2f0263c194e 4f67a218c75cfc9cf67e.pdf. Acesso em 28 set. 2019.

DEFENSORIA PÚBLICA DO ESTADO DO RIO DE JANEIRO. Relatório: um ano de audiência de custódia no Rio de Janeiro. Rio de Janeiro: DPERJ, 2016. Disponível em: http://www.defensoria.rj.def.br/uploads/arquivos/53f2bf4ac82541 d3a0aa8bc6c6243c3e.pdf. Acesso em 28 set. 2019.

FEDERAÇÃO NACIONAL DOS DELEGADOS DE POLÍCIA FEDERAL. Ofício n 37/14-FENADEPOL. Ref.: PLS 554/2011. Brasília: FENADEPOL, 4 ago. 2014.

INSTITUTO DE DEFESA DO DIREITO DE DEFESA. O fim da liberdade: a urgência de recuperar o sentido e a efetividade das audiências de custódia. São Paulo: IDDD, 2019. Disponível em: http://www.iddd.org.br/wp-content/uploads/2020/07/OFimDaLiberdade_completo.pdf. Acesso em 28 set. 2019.

JACOBSEN, Gabriel. Algemados a 18 viaturas, quase cem presos vivem em "cadeia a céu aberto" em Porto Alegre. Jornal GaúchaZH, Porto Alegre, 25 set. 2019. Disponível em:

https://gauchazh.clicrbs.com.br/seguranca/noticia/2019/09/algemados-a-18-viaturas-quasecem-presos-vivem-em-cadeia-a-ceu-aberto-em-porto-alegre-ck0zjtvte00p701mtpx6x76o1.html. Acesso em: 28 set. 2019.

Jacobson, Jessica, HEARD, Catherine e FAIR, Helen. Prison: Evidence of its use and over-use from around the world. Londres: Institute for Criminal Policy Research, 2017.

LEMGRUBER, Julita; FERNANDES, Márcia; CANO, Ignacio; MUSUMECI, Leonarda. Usos e abusos da prisão provisória no Rio de Janeiro: avaliação de impacto da Lei 12.403/2011 Rio de Janeiro: ARP/CESeC, 2013.

LEWANDOWSKI e Marco Aurélio criticam escalada do punitivismo no Brasil. CONJUR, São Paulo, 26 abr. 2015, 14:52. Disponível em: https://www.conjur.com.br/2015-abr-26/juizes-discursamdurante-lancamento-anuario-justica-brasil. Acesso em 28 set. 2019.

MARIZ, Renata. Diretor-Geral penitenciário diz que país precisa de 20 mil a 25 mil vagas por ano para resolver o déficit. Jornal O Globo, Rio de Janeiro, 22 set. 2019. Disponível em: <https://glo.bo/2LC6QLd>. Acesso em: 29 set.2019.

PAIVA, Caio. Audiência de custódia e o processo penal brasileiro. 3. ed. Boa Esperança-MG: Editora CEI, 2018, E-book. 
PALMA, Mauro. O caso italiano a partir de uma sentença piloto. Epílogo da obra de BEIRAS, Iñaki Rivera. Desencarceramento: por uma política de redução da prisão a partir de um garantismo radical. Florianópolis: Tirant Lo Blanch, 2019.

PASTORAL CARCERÁRIA. Luta antiprisional no mundo contemporâneo: um estudo sobre experiências de redução da população carcerária em outras nações. São Paulo: Pastoral Carcerária, 2018. Disponível em: https://carceraria.org.br/wpcontent/uploads/2018/09/relatorio_luta_antiprisional.pdf. Acesso em 28 set. 2019.

RIO DE JANEIRO (Estado). Órgão Especial do Tribunal de Justiça. Resolução $\mathrm{n}^{\circ}$ 14, de 16 out. 2017. Diário da Justiça Eletrônico do Estado do Rio de Janeiro: ADM: Poder Judiciário, n. 34, p. 18, 24 out. 2017.

RIO DE JANEIRO (Estado). Órgão Especial do Tribunal de Justiça. Resolução $n^{\circ} 29$, de 24 ago. 2015. Diário da Justiça Eletrônico do Estado do Rio de Janeiro: ADM: Poder Judiciário, n. 8, p. 20, 11 nov. 2015.

RIO DE JANEIRO (Estado). Secretaria de Administração Penitenciário do Estado do Rio de Janeiro. Consolidação Dados. Rio de Janeiro: SEAPRJ, 19 ago. 2019.

SINHORETO, Jacqueline; LIMA, Renato Sérgio de. Narrativa autoritária e pressões democráticas na segurança pública e no controle do crime. Contemporânea - Revista de Sociologia da UFSCar, Salvador, v. 5, n. 1, p. 119-141, jan./jun. 2015.

TJ do Rio vai se integrar ao banco de monitoramento de prisões do CNJ. Tribunal de Justiça do Estado do Rio de Janeiro, Rio de Janeiro, 6 fev. 2018. Disponível em: http://gmf.tjrj.jus.br/web/gmf/noticias/noticia/-/visualizar-conteudo/5265985/5278701. Acesso em 28 set. 2019.

TRIBUNAL DE JUSTIÇA DE SÃO PAULO. Corregedoria Geral da Justiça. Parecer. Processo no 2014/00153634. Corregedor Geral de Justiça: Des. Hamilton Elliot Akel, 30 out. 2014.

TRIBUNAL DE JUSTIÇA DO ESTADO DO RIO DE JANEIRO. Grupo de Monitoramento e Fiscalização do Sistema Carcerário. Censo Sistema Prisional. Rio de Janeiro: TJRJ, 2019. Disponível em: http://gmf.tjrj.jus.br/censo-sistema-prisional. Acesso em 28 set. 2019.

VIANNA, Luiz Werneck; CARVALHO, Maria Alice Rezende de; BURGOS, Marcelo Baumann. Quem somos: a magistratura que queremos. Rio de Janeiro: Associação dos Magistrados Brasileiros, 2018.

WALMSLEY, Roy. World Prison Population List. 12th ed. Londres: Institute For Criminal Policy Research, 06 nov. 2018. Disponível em:

https://www.prisonstudies.org/sites/default/files/resources/downloads/wppl_12.pdf. Acesso em 28 set. 2019.

ZAFFARONI, Eugenio Raúl. 'Cada país tem o número de presos que decide politicamente ter'. [Entrevista cedida a] Viviane Tavares. EPSJV/Fiocruz, Rio de Janeiro, 15 jul. 2013, 8:45, atualizado em 05 abr. 2016, 11:47. Disponível em: http://www.epsjv.fiocruz.br/noticias/entrevista/cadapais-tem-o-numero-de-presos-que-decide-politicamente-ter. Acesso em: 28 set. 2019. 


\section{Thaís Lima}

Mestranda em Direito Público e Graduada em Direito pela Universidade do Estado do Rio de Janeiro. Defensora Pública do Estado do Rio de Janeiro. Atuou junto ao Supremo Tribunal Federal e Superior Tribunal de Justiça entre 2014 e 2016.

\section{Enviado em: 22 de novembro de 2020}

\section{Aprovado em: 04 de fevereiro de 2021}

